\title{
Size and Value in the Stock Exchange of Thailand
}

\author{
Mussa Hussaini \\ School of Management, Asian Institute of Technology, Pathumthani, Thailand \\ Email: hussainimussa@gmail.com
}

Received 28 January 2016; accepted 8 March 2016; published 11 March 2016

Copyright $@ 2016$ by authors and Scientific Research Publishing Inc.

This work is licensed under the Creative Commons Attribution International License (CC BY). http://creativecommons.org/licenses/by/4.0/

(c) (i) Open Access

\begin{abstract}
The existences of size premium and value premium in stock markets have been well studied. However, these studies mostly focus on U.S. market and have been limited in countries such as Thailand. In the Stock Exchange of Thailand, we examined the performance of small stocks portfolios versus large stocks portfolios and value stocks portfolios versus growth stocks portfolios for the period of 1999 through 2013. Returns on portfolios are calculated on a monthly basis. Our findings are: first, there is a size premium in the Stock Exchange of Thailand and the difference between the average monthly returns is $\mathbf{2 . 0 2}$ percent; second, value stocks do not generate higher average monthly returns than growth stocks and it is true for both small size stocks and large size stocks.
\end{abstract}

\section{Keywords}

Small Stocks, Large Stocks, Value Stocks, Growth Stocks, Stock Exchange of Thailand

\section{Introduction}

Stocks are usually classified according to their characteristics which are unique enough such that the performance of each category can be differentiated from another. Barberis \& Shleifer (2003) contend that the reasons behind such classifications in financial market are sometimes financial innovation or it can also be because of finding a premium in a group of stocks with similar features. The major classifications of stocks can be broken into following categories: The first classification is small-cap and large-cap. Capitalization level is probably the most common way to classify and differentiate stocks in stock market and Banz (1981) is one of the first scholars who classify stock based on their market value. The second most common classification is value and growth stocks. Value stocks are those that have low price to book (P/B), price to earnings $(\mathrm{P} / \mathrm{E})$, and price to cash flow $(\mathrm{P} / \mathrm{C})$ ratios while growth stocks are those that have high price to book $(\mathrm{P} / \mathrm{B})$, price to earnings $(\mathrm{P} / \mathrm{E})$, and price 
to cash flow (P/C) ratios (Graham \& Dodd, 1934). Many other scholars like Lakonishok, Shleifer, \& Vishny (1994) and Fama \& French (1998) also share this distinction. The performances of these classifications have been well documented in numerous studies in different countries. These studies suggest that small stocks generate higher return than large stocks (size effect). See e.g. Banz (1981), Bauman, Conover, \& Miller (1998) and value stocks outperform growth stocks (value premium). See e.g. Bauman et al., (1998), Fama \& French (1992, 1998, 2012). Given the visible existence of an academic gap of such a study in Thailand, this study, therefore, intends to examine the performance of these classifications in stocks by showcasing the Stock Exchange of Thailand in the aftermath of 1997 financial crisis.

Studies by Chui \& Wei (1998) are suggestive of the fact that equity market size in Thailand increased from $\$ 1.72$ billion in 1984 to $\$ 133.66$ billion in 1993, an increase of over 77 times within a decade. Thailand is notably a free market economy with intensified objectives of attracting Foreign Direct Investment (FDI) in all sectors of the economy and as such, the Stock Exchange of Thailand is at the spotlight of attracting international investors. Scholarly studies by Lipsey (2000) attribute to the fact that FDI contributes significantly to economic development through job creation, technology transfers and spillovers, and thus the Stock Market of Thailand is a major channel for FDI flows. Therefore, this study plays a significant role in investigating information that is of particular relevance to investors with regard to the Thai equity market. Previous studies have entirely focused on large stocks, ignoring the crucial need to equally analyze small stocks. This paper explores a distinctive approach to include small and tiny stocks in order to widen the academic and market scopes of small-caps and large-caps and value and growth stocks. Further, there is a visible distinct absence of detailed academic research on small-caps and large-caps and value and growth stocks in the Stock Exchange of Thailand especially after the crisis and this paper seeks to bridge the academic gap and also provides new frontiers of knowledge for prospective scholars in different countries.

In Section 2 of the paper, an exploration is made into the most recent/previous academic literature for each classification in different markets. Third section contains the data analysis. Research design and methodology which are used to carry out the study are presented in the fourth section of the paper, while the fifth section presents the findings of the study and conclusions are made in Section 6.

\section{Literature Review}

\subsection{Size Effect (SMB)}

In US market, Banz (1981) analyzes the performance of small and large stocks and finds that there is a negative relationship between size of the company and its returns during the period of 1936 to 1975 in New York Stock Exchange and argues that the size effect is stronger in smallest companies. Banz (1981) further concludes that the size effect is not stable; in other word in some years of the study large stocks generate higher return but on average small stocks performed better compared to large stocks. Some scholars have studied size effect with a greater focus on Asian countries; Chen \& Zhang (1998) investigate six countries namely; Japan, Malaysia, Taiwan, Hong Kong, Thailand, and United State and they find that except in Taiwan, small stocks tend to generate higher return than large stocks in all the other countries studied. Chen \& Zhang (1998) further contend that the difference between average return of smallest and largest stocks is 1.301 percent over the period of 1978 to 1993 in Thailand. Chui \& Wei (1998) also study the size effect in Thailand, Malaysia, Taiwan, Korea, and Hong Kong and their result show that there is size effect in each of these countries over the period of 1977 to 1993 and more specifically over the period of 1984 to 1993 in Thailand. However, Ding, Chua, \& Fetherston (2005) find a weak size effect in Thailand over the period of 1976 to 1997. Fama \& French (2012) investigate four regions namely; North America, Europe, Japan, and Asia pacific and interestingly they find no evidence of size premium and conclude that the average SMB (small minus big) returns are all close to zero in all four regions studied during their sample period of 1991 to 2010.

\subsection{Value Premium (VMG)}

Fama \& French (1992) examine the existing of value premium (value minus growth) in US market for the period of 1962 to 1989 and find positive value premium. In the international context, Capaul, Rowley, \& Sharpe (1993) examine value stocks and growth stocks in six countries namely; Japan, US, Germany, UK, France, and Switzerland between 1981 and 1992 and find that the portfolios of value stocks generate both higher average 
return and higher average risk-adjusted return than portfolios of growth stocks in these countries. Chen \& Zhang (1998) investigate and compare the value premium in different countries including Thailand over a 15 year period between 1978 and 1993 and find no reliable evidence of value premium in their study period in these countries including Thailand. Chui \& Wei (1998) also study the value premium in Thailand and other Asian countries; Hong Kong, Korea, Malaysia, and Taiwan over the period of 1977 to 1993 and find that there is no positive relationship between the portfolio returns and B/M ratio in Thailand during the period of 1984 to 1993. Ding et al. (2005) also investigate the Asian market before the Asian financial crisis and find that value premium is significant for, Japan, Malaysia, Hong Kong, and Singapore and largely insignificant for Indonesia and Taiwan while it is negative for Thailand. These findings are also consistent with findings of Chui \& Wei (1998). Ding et al. (2005) argue that in Thailand, growth stocks with a large firm size generate higher average returns. Fama \& French (2012) study value and growth stocks in four regions namely; North America, Europe, Japan, and Asia Pacific, and find that on average there is value premium for all the regions studied. Fama \& French (2012) further argue that value premium is greater for small stocks.

\section{Data Analysis}

In order to study size effect and value premium in Thailand, a 15 years sample period from March 1999 to February 2014 is covered. All data are extracted from Stock Exchange of Thailand database (SET Smart), accessed from and available with the Business Research Center at the Thammasat University. SET Smart database contains historical trading prices and indices, listed companies, key statistics information, and information and news. An argument by Yen, Sun, \& Yan (2004) attributes part of the premium to size effect. This study adopts an approach which proved to be successful in portfolio formation by Basu (1983) and Fama \& French (2012). The approach argues for the use of a two-dimension sort in construction of portfolios. Stocks are sorted on size and P/B. On size-P/B sort, portfolios are constructed at the beginning of February of each year and then evaluated for the next 12 months on monthly basis. For a stock to be included in these portfolios, it should have financial data at the portfolios construction stage and then should be traded at least for the next 1 year. If any stock does not satisfy these conditions, it is eliminated from the sample. Additionally, in order to eliminate bias in the final result of the premium, scholars such as Yen et al. (2004) argue for the need to remove financial companies from their samples owing to the fact that financial companies have different structures. However, the approach adopted by this study concurs with Barber \& Lyon (1997) who compared two samples; one with and the other without financial companies and their findings had it that the general final result is not affected by adding financial companies into the sample. In this study financial companies are not excluded from the sample.

\section{Methodology}

At the end of February of each year, stocks are sorted based on their market capitalization in descending order. Month of February is used to be aligned with the result and announcing of the listed company in the stock exchange of Thailand. Stocks in the top 10\% are considered as large stocks and stocks in bottom the $10 \%$ are considered as small stocks. Then, in each size class stocks are ranked based on their price-to-book ratio from highest to lowest. In each size category the top $30 \%$ of the companies with the highest $\mathrm{P} / \mathrm{B}$ ratio are selected to form the size-adjusted growth stocks, and the bottoms $30 \%$ of the companies with lowest P/B ratio are selected to form the size-adjusted value stocks. The middle $40 \%$ are considered as neutral stocks. This is similar to the method employed by Fama \& French (2012). Based on this method 6 portfolios are constructed on size-P/B sort which are; SV, SN, SG, BV, BN, and BG, where S and B indicate small and big stocks while V, N, and G indicate value, neutral, and growth (bottom $30 \%$, middle $40 \%$, and top 30\%), respectively. After forming portfolios for year $t$, portfolios are evaluated on monthly basis using continuously compounded method and Sharpe ratio for the next 12 months starting from March of year $t$ and ending in February of year $t+1$.

According to Fama \& French (1998) stocks in a portfolio can be weighted in two ways; equal-weighted and value-weighted. Chui, Wei, \& Titman (2000) use the value-weighted method in their study of Asian market with the rationale that small stocks are less liquid in Asian market. Ding et al. (2005) also use the value-weighted method and argue that it is logical that stocks with big market capitalization should have a bigger share in a portfolios' return. In this study, following Fama \& French (2012) we use the value-weighted method and accordingly stocks are weighted in each portfolio based on their market capitalization. After calculation of the monthly return on each of these portfolios, size effect (SMB) is calculated using fowling formula: 


$$
\begin{aligned}
\mathrm{SMB}= & (\text { Equal weight average of the return on SV,SN and SG }) \\
& -(\text { Equal weight average of the return on BV, BN and BG })
\end{aligned}
$$

where, S stands for small stocks and B stands for large stocks, V, N, and G denote value, neutral, and growth stocks, respectively.

Value premium (VMG) is calculated for each size category ( $\mathrm{VMG}_{\mathrm{S}}$ and $\mathrm{VMG}_{\mathrm{B}}$ ) and then the overall value premium is the equal weight of value premium in each size. Formula can be written as follow:

$$
\begin{gathered}
\mathrm{VMG}_{\mathrm{S}}=\mathrm{SV}-\mathrm{SG} \\
\mathrm{VMG}_{\mathrm{B}}=\mathrm{BV}-\mathrm{BG} \\
\mathrm{VMG}=\text { Equal weight of } \mathrm{VMG}_{\mathrm{S}} \text { and } \mathrm{VMG}_{\mathrm{B}}
\end{gathered}
$$

where, S stands for small stocks and B stands for large stocks, V and G denote value stocks and growth stocks, respectively.

According to Yen et al. (2004) stocks and portfolios should be evaluated both in terms of total return and risk adjusted return. In this study, we use the Sharpe ratio for measuring the portfolios performances per unit of risk. Sharpe ratio is calculated for each portfolio formed based on size-P/B namely; SV, SN, SG, BV, BN, and BG. The Sharpe ratio formula can be written as follow:

$$
\text { Sharpe ratio }=\frac{\bar{R}_{p}-\bar{r}_{f}}{\sigma_{p}}
$$

where, $\bar{R}_{p}$ is the average return of the portfolio for a certain period of time which is monthly return in this study, $\bar{r}_{f}$ is risk free rate within the same period of time, and $\sigma_{p}$ is the standard deviation of the portfolio.

The chances that governments default on an obligation denominated in its own currency are almost zero so Treasury bill and government bond are totally risk free rate (Hull, 2011). In this study, Thailand government Bond 10 years is used as risk free rate.

\section{Findings and Discussion}

In Appendix, Table A1 summarizes the performance of the 6 portfolios formed based on size-P/B, namely; SV, SN, SG, BV, BN, and BG between 1999 and 2013. The result in panel A demonstrates that, there is no statistical difference between average monthly returns of small-value stock portfolios and small-growth stock portfolios. Small-value stock portfolios provide higher average monthly returns than small-growth stock portfolios in 10 out of 15 years; however, the difference is a statistically significant in only two of these ten years. The results indicate that small-value stock portfolios do not outperformed the small-growth stock portfolios. In other word, there is no value premium in small size category during the period of study. The average monthly value premium in small stock category ( $\mathrm{VMG}_{\mathrm{S}}$ ) is 0.18 percent with the $t$-value of 0.1490 . Furthermore, an analysis of average monthly risk-adjusted returns also yield similar results as those of average monthly returns, wherein a higher average monthly risk-adjusted return is noted in 10 of 15 years, but the difference is statistically significant only for two of these ten years, leading us to the conclusion that small-value stock portfolios do not provide higher average monthly risk-adjusted returns than small-growth stock portfolios, with the mean difference of 3.7 percent and the $t$-value of 0.309 .

The results in panel B report that there is statistical indifference in average monthly returns of large-value stock portfolios and large-growth stock portfolios. Large-value stock portfolios generate higher average monthly returns than large-growth stock portfolios in only 6 of 15 years of the study period and among these six years only one year is statistically significant. The result is conclusive evidence that large-value stock portfolios do not outperformed large-growth stock portfolios in the study period. In other word, there is no value premium in the large size category as well. The average monthly value premium in large size category ( $\left.\mathrm{VMG}_{\mathrm{B}}\right)$ is 0.21 percent with the $t$-value of 0.232 . Furthermore, although large-value stock portfolios generate higher average monthly risk-adjusted return than large-growth stock portfolios in 7 of the 15 years, the results are not statistically significant in any of these seven years. Average results indicate that the large-value stock portfolios do not gain higher average monthly risk-adjusted returns than large-growth stock portfolios with a mean difference of -0.4 percent and a $t$-value of -0.04 . 
Panel C reports the difference between small stock portfolios and large stocks portfolios (SMB). Small stock portfolios generate higher average monthly returns than large stocks portfolios in 11 of 15 the years of the study period. But this is statistically significant in only two of the eleven years. The result demonstrates that small stocks outperform large stocks with the mean of 2.02 percent and the t-value of 2.22 over the period of 1999 to 2013. This finding is in line with previous studies such as those conducted by Chui \& Wei (1998) who find that there is significant size effect in all five countries covered in their study, namely: Thailand, Malaysia, Taiwan, Korea, and Hong Kong over the period of 1977 to 1993. Chen \& Zhang (1998) also find that in the six countries covered in their study including Thailand, except for Taiwan, small stocks tend to generate higher return than large stocks in all the countries studied. However, Ding et al. (2005) by investigating the performance of stocks in seven Asian markets before Asian crisis including Thailand over the period of 1976 to 1997 find a weak size effect in Indonesia and Thailand.

In panel D results indicate that there is no value premium (VMG) in Thailand during the period of 1999 to 2013. In other word, value stock portfolios do not outperform growth stock portfolios. Although, average monthly value premium is positive in 10 of the 15 years, it is statistically significant in only two of the ten years. Overall, the average monthly value premium over the period of the study is 0.2 percent with the t-value of 0.216 . The result of the study is consistent with previous studies of value premium in Thailand; Chen \& Zhang (1998) examine and compare the value investing in different countries including Thailand over the period of 1978 to 1993 and they find that there is no reliable value premium in Thailand. Chui \& Wei (1998) also examine the value premium in five Asian countries including Thailand and they find that there is no positive relationship between the portfolio returns and B/M ratio in Thailand during the period of 1984 to 1993. Ding et al. (2005) also find that there is a negative value premium in Thailand for the period of 1976 to 1997.

\section{Conclusion}

Given the above findings, we can conclude the following: In the context of Thailand, academic studies document that there is a size effect in Thai equity market before crisis. Our findings provide no conclusive evidence of change from such pre crisis patterns in Thailand. We found that there was a size effect in SET over the period of 1999 through 2013 (after crisis). The difference between equal-weight averages of the monthly returns on small stock portfolios and large stock portfolios is 2.02 percent. Although, small stocks do not provide higher return in all years of the study period, on average, the returns are statistically higher for small stocks as compared to large stock portfolios. Further, no matter whether value and growth portfolios were formed based on $\mathrm{P} / \mathrm{B}$ in each size category, the same as in the pre-crisis period in Thailand, we also did not find any evidence of value premium in SET during the period of 1999 to 2013 (after crisis). Practically value stocks provide higher average monthly returns in most of the years of the study period, but they are not statistically significant.

\section{References}

Banz, R. W. (1981). The Relationship between Return and Market Value of Common Stocks. Journal of Financial Economics, 9, 3-18. http://dx.doi.org/10.1016/0304-405X(81)90018-0

Barber, B. M., \& Lyon, J. D. (1997). Detecting Long-Run Abnormal Stock Returns: The Empirical Power and Specification of Test Statistics. Journal of Financial Economics, 43, 341-372. http://dx.doi.org/10.1016/S0304-405X(96)00890-2

Barberis, N., \& Shleifer, A. (2003). Style Investing. Journal of Financial Economics, 68, 161-199. http://dx.doi.org/10.1016/S0304-405X(03)00064-3

Basu, S. (1983). The Relationship between Earnings' Yield, Market Value and Return for NYSE Common Stocks: Further Evidence. Journal of Financial Economics, 12, 129-156. http://dx.doi.org/10.1016/0304-405X(83)90031-4

Bauman, W. S., Conover, C. M., \& Miller, R. E. (1998). Growth versus Value and Large-Cap versus Small-Cap Stocks in International Markets. Financial Analysts Journal, 54, 75-89. http://dx.doi.org/10.2469/faj.v54.n2.2168

Capaul, C., Rowley, I., \& Sharpe, W. F. (1993). International Value and Growth Stock Returns. Financial Analysts Journal, 49, 27-36.

Chui, A.C., Wei, K.-C., \& Titman, S. (2000). Momentum, Legal Systems and Ownership Structure: An Analysis of Asian Stock Markets. SSRN Scholarly Paper No. ID 265848, Rochester, NY: Social Science Research Network.

Chui, A. C. W., \& Wei, K. C. J. (1998). Book-to-Market, Firm Size, and the Turn-of-the-Year Effect: Evidence from Pacific-Basin Emerging Markets. Pacific-Basin Finance Journal, 6, 275-293. http://dx.doi.org/10.1016/S0927-538X(98)00013-4 
Ding, D. K., Chua, J. L., \& Fetherston, T. A. (2005). The Performance of Value and Growth Portfolios in East Asia before the Asian Financial Crisis. Pacific-Basin Finance Journal, 13, 185-199. http://dx.doi.org/10.1016/j.pacfin.2004.07.001

Fama, E. F., \& French, K. R. (1992). The Cross-Section of Expected Stock Returns. The Journal of Finance, 47, 427-465. http://dx.doi.org/10.1111/j.1540-6261.1992.tb04398.x

Fama, E. F., \& French, K. R. (1998). Value versus Growth: The International Evidence. The Journal of Finance, 53, 19751999. http://dx.doi.org/10.1111/0022-1082.00080

Fama, E. F., \& French, K. R. (2012). Size, Value, and Momentum in International Stock Returns. Journal of Financial Economics, 105, 457-472. http://dx.doi.org/10.1016/j.jfineco.2012.05.011

Graham, B., \& Dodd, D. L. F. (1934). Security Analysis. New York, NY: McGraw-Hill Education.

Hull, J. C. (2011). Fundamentals of Futures and Options Markets (Global Edition). Boston, MA: Pearson Education, Inc.

Lakonishok, J., Shleifer, A., \& Vishny, R. W. (1994). Contrarian Investment, Extrapolation, and Risk. The Journal of Finance, 49, 1541-1578. http://dx.doi.org/10.1111/j.1540-6261.1994.tb04772.x

Lipsey, R. E. (2000). The Role of Foreign Direct Investment in International Capital Flows. NBER Working Papers 7094.

Chen, N.-F., \& Zhang, F. (1998). Risk and Return of Value Stocks. The Journal of Business, 71, 501-535. http://dx.doi.org/10.1086/209755

Yen, J. Y., Sun, Q., \& Yan, Y. (2004). Value versus Growth Stocks in Singapore. Journal of Multinational Financial Management, 14, 19-34. http://dx.doi.org/10.1016/S1042-444X(03)00036-7 


\title{
Appendix
}

Table A1. Summary statistics for portfolios on size-P/B; March 1999-February 2014, 180 months. (a) Small stocks portfolios; (b) Big stocks portfolios; (c) Small—Big; (d) Value-Growth.

\author{
(a)
}

\begin{tabular}{|c|c|c|c|c|c|c|c|c|c|c|c|c|c|c|c|c|}
\hline & \multicolumn{15}{|c|}{ Year } & \multirow{2}{*}{$\begin{array}{c}\text { Average } \\
\text { 1999-2013 }\end{array}$} \\
\hline & 1999 & 2000 & 2001 & 2002 & 2003 & 2004 & 2005 & 2006 & 2007 & 2008 & 2009 & 2010 & 2011 & 2012 & 2013 & \\
\hline \multicolumn{17}{|c|}{ Average monthly portfolios return (\%) } \\
\hline SV & 7.90 & 0.88 & 10.93 & 8.14 & 6.64 & -0.40 & 0.59 & 2.00 & 0.55 & -2.15 & 7.63 & 4.05 & 1.18 & 5.22 & 0.15 & 3.56 \\
\hline SN & 6.65 & 3.84 & 3.33 & 6.06 & 4.33 & -0.54 & 0.93 & 2.03 & 1.15 & -4.21 & 7.48 & 2.53 & 0.01 & 6.89 & 2.72 & 2.88 \\
\hline SG & 5.46 & 1.83 & 9.20 & 2.46 & 11.31 & 3.92 & -0.02 & -1.72 & 0.02 & -4.01 & 3.97 & 2.17 & 7.75 & 8.57 & -0.18 & 3.38 \\
\hline \multicolumn{17}{|c|}{ Standard Deviation of portfolios $\sigma_{p}$ (\%) } \\
\hline SV & 20.94 & 6.33 & 16.49 & 7.60 & 9.24 & 2.78 & 3.82 & 5.37 & 2.55 & 9.57 & 8.08 & 10.47 & 6.56 & 5.57 & 9.70 & 8.34 \\
\hline SN & 20.49 & 6.06 & 12.08 & 6.48 & 5.80 & 3.51 & 2.70 & 3.88 & 3.61 & 13.20 & 5.77 & 6.72 & 6.31 & 6.53 & 7.76 & 7.39 \\
\hline SG & 20.55 & 9.54 & 16.75 & 8.99 & 16.51 & 9.17 & 2.82 & 6.18 & 3.26 & 12.14 & 6.56 & 4.65 & 11.53 & 5.29 & 8.09 & 9.47 \\
\hline \multicolumn{17}{|c|}{ Sharpe Ratio: $\overline{\left(R_{p}-R_{f}\right)} / \sigma_{p}(\times 100)$} \\
\hline SV & 0.35 & 0.06 & 0.63 & 1.02 & 0.69 & -0.29 & 0.04 & 0.29 & 0.07 & -0.26 & 0.90 & 0.36 & 0.13 & 0.88 & -0.02 & 0.32 \\
\hline SN & 0.29 & 0.55 & 0.24 & 0.88 & 0.69 & -0.27 & 0.19 & 0.41 & 0.21 & -0.35 & 1.24 & 0.33 & -0.05 & 1.01 & 0.31 & 0.38 \\
\hline SG & 0.23 & 0.14 & 0.52 & 0.23 & 0.67 & 0.38 & -0.16 & -0.35 & -0.11 & -0.36 & 0.55 & 0.40 & 0.65 & 1.56 & -0.06 & 0.29 \\
\hline \multicolumn{17}{|c|}{ Difference in S.D $\sigma_{p}$ (\%) } \\
\hline SV-SG & 0.39 & -3.21 & -0.27 & -1.39 & -7.26 & -6.39 & 1.00 & -0.81 & -0.72 & -2.57 & 1.53 & 5.83 & -4.97 & 0.29 & 1.61 & -1.13 \\
\hline \multicolumn{17}{|c|}{ Difference in returns $\left(\mathrm{WMG}_{\mathrm{S}}\right)(\%)$} \\
\hline & 2.51 & -0.95 & 1.73 & 5.69 & -4.67 & -4.32 & 0.60 & 3.71 & 0.53 & 1.86 & 3.65 & 1.89 & -6.57 & -3.35 & 0.33 & 0.18 \\
\hline & $(0.283)$ & $(-0.319)$ & $(0.247)$ & $(1.547)^{*}$ & $(-0.849)$ & $(-0.76)$ & $(0.426)$ & $(1.555)^{*}$ & $(0.435)$ & $(0.42)$ & $(1.2)$ & $(0.558)$ & $(-1.673)^{*}$ & $(-1.21)$ & $(0.093)$ & $(0.149)$ \\
\hline \multicolumn{17}{|c|}{ Difference in Sharpe ratio $(\times 100)$} \\
\hline SV - SG & 0.12 & -0.08 & 0.11 & 0.79 & 0.02 & -0.67 & 0.20 & 0.64 & 0.18 & 0.10 & 0.35 & -0.04 & -0.51 & -0.68 & 0.04 & 0.037 \\
\hline & $(0.27)$ & $(-0.205)$ & $(0.269)$ & $(1.788)^{* *}$ & $(0.044)$ & $(-0.991)$ & $(0.471)$ & $(1.541)^{*}$ & $(0.426)$ & $(0.239)$ & $(0.84)$ & $(-0.108)$ & $(-1.228)($ & $(-1.332)^{*}$ & $(0.113)$ & $(0.309)$ \\
\hline
\end{tabular}

(b)

\begin{tabular}{|c|c|c|c|c|c|c|c|c|c|c|c|c|c|c|c|c|}
\hline \multicolumn{17}{|c|}{ Average monthly portfolios return (\%) } \\
\hline $\mathrm{BV}$ & -0.28 & -0.05 & 3.97 & 1.92 & 3.53 & 0.35 & 0.64 & 0.16 & 0.61 & -5.34 & 8.58 & 3.42 & 1.28 & 2.92 & -0.81 & 1.39 \\
\hline $\mathrm{BN}$ & 2.23 & -0.50 & 1.17 & -0.75 & 7.02 & 1.29 & 0.06 & -0.32 & 3.23 & -5.94 & 4.54 & 3.26 & 1.77 & 1.27 & -0.47 & 1.19 \\
\hline BG & 1.25 & -2.38 & -0.51 & 0.17 & 6.57 & 1.72 & 1.08 & -0.53 & 2.93 & -3.96 & 3.28 & 2.26 & 2.96 & 3.37 & -0.48 & 1.18 \\
\hline \multicolumn{17}{|c|}{ Standard Deviation of portfolios $\sigma_{p}(\%)$} \\
\hline BV & 19.10 & 14.66 & 9.85 & 7.60 & 7.43 & 4.39 & 4.59 & 5.77 & 6.07 & 12.38 & 9.28 & 5.57 & 6.62 & 4.45 & 2.97 & 8.05 \\
\hline $\mathrm{BN}$ & 12.89 & 9.48 & 11.56 & 6.42 & 9.31 & 3.52 & 4.26 & 5.03 & 7.81 & 13.00 & 7.02 & 5.12 & 8.24 & 4.04 & 6.18 & 7.59 \\
\hline $\mathrm{BV}$ & 14.36 & 11.59 & 9.54 & 4.86 & 8.31 & 5.98 & 6.57 & 4.19 & 6.69 & 11.93 & 5.96 & 4.38 & 5.67 & 5.78 & 6.85 & 7.51 \\
\hline \multicolumn{17}{|c|}{ Sharpe Ratio: $\overline{\left(R_{p}-R_{f}\right)} / \sigma_{p}(\times 100)$} \\
\hline BV & -0.05 & -0.04 & 0.35 & 0.20 & 0.43 & -0.01 & 0.05 & -0.05 & 0.04 & -0.46 & 0.89 & 0.56 & 0.15 & 0.59 & -0.38 & 0.15 \\
\hline $\mathrm{BN}$ & 0.12 & -0.10 & 0.06 & -0.17 & 0.72 & 0.25 & -0.09 & -0.15 & 0.37 & -0.49 & 0.60 & 0.58 & 0.18 & 0.24 & -0.13 & 0.13 \\
\hline BG & 0.04 & -0.25 & -0.10 & -0.04 & 0.75 & 0.22 & 0.10 & -0.23 & 0.38 & -0.36 & 0.49 & 0.45 & 0.47 & 0.53 & -0.12 & 0.16 \\
\hline \multicolumn{17}{|c|}{ Difference in S.D $\sigma_{p}(\%)$} \\
\hline $\mathrm{BV}-\mathrm{BG}$ & 4.74 & 3.07 & 0.31 & 2.74 & -0.87 & -1.59 & -1.99 & 1.58 & -0.62 & 0.45 & 3.33 & 1.20 & 0.95 & -1.33 & -3.87 & 0.54 \\
\hline \multicolumn{17}{|c|}{ Difference in returns $\left(\mathrm{WMG}_{\mathrm{B}}\right)(\%)$} \\
\hline$R_{\mathrm{BV}}-R_{\mathrm{BG}}$ & $\begin{array}{c}-1.53 \\
(-0.226)\end{array}$ & $\begin{array}{c}2.33 \\
(0.43)\end{array}$ & $\begin{array}{c}4.48 \\
(1.137)\end{array}$ & $\begin{array}{c}1.74 \\
(0.681)\end{array}$ & $\begin{array}{c}-3.04 \\
(-0.902)\end{array}$ & $\begin{array}{c}-1.38 \\
(-0.633)\end{array}$ & $\begin{array}{c}-0.43 \\
(-0.186)\end{array}$ & $\begin{array}{c}0.69 \\
(0.338)\end{array}$ & $\begin{array}{c}-2.32 \\
(-0.893)\end{array}$ & $\begin{array}{c}-1.38 \\
(-0.283)\end{array}$ & $\begin{array}{c}5.30 \\
(1.653)^{*}\end{array}$ & $\begin{array}{c}1.16 \\
(0.567)\end{array}$ & $\begin{array}{c}-1.68 \\
(-0.704)\end{array}$ & $\begin{array}{c}-0.45 \\
(-0.282)\end{array}$ & $\begin{array}{c}-0.33 \\
(-0.159)\end{array}$ & $\begin{array}{c}0.21 \\
(0.232)\end{array}$ \\
\hline \multicolumn{17}{|c|}{ Difference in Sharpe ratio $(\times 100)$} \\
\hline$B$ & -0.09 & 0.21 & 0.46 & 0.24 & -0.32 & -0.23 & -0.05 & 0.18 & -0.34 & -0.10 & 0.39 & 0.11 & -0.32 & 0.06 & -0.26 & -0.004 \\
\hline- BG & $(-0.226)$ & $(0.515)$ & $(1.129)$ & $(0.62)$ & $(-0.746)$ & $(-0.566)$ & $(-0.126)$ & $(0.452)$ & $(-0.843)$ & $(-0.245)$ & (0.958) & $(0.274)$ & $(-0.831)$ & (0.179) & $(-0.664)$ & $(-0.04)$ \\
\hline
\end{tabular}


(c)

\begin{tabular}{|c|c|c|c|c|c|c|c|c|c|c|c|c|c|c|c|c|}
\hline \multicolumn{17}{|c|}{ Equal weight of the returns (\%) } \\
\hline $\begin{array}{l}\text { SV, SN, } \\
\text { and SG }\end{array}$ & 6.69 & 2.18 & 7.82 & 5.55 & 7.43 & 0.99 & 0.50 & 0.77 & 0.57 & -3.46 & 6.36 & 2.92 & 2.98 & 6.89 & 0.90 & 3.27 \\
\hline $\begin{array}{l}\mathrm{BV}, \mathrm{BN} \text {, } \\
\text { and } \mathrm{BG}\end{array}$ & 1.07 & -0.98 & 1.54 & 0.44 & 5.70 & 1.12 & 0.59 & -0.23 & 2.26 & -5.08 & 5.47 & 2.98 & 2.00 & 2.52 & -0.58 & 1.26 \\
\hline \multicolumn{17}{|c|}{ Difference in returns (\%) } \\
\hline \multirow[b]{2}{*}{ SMB } & 5.63 & 3.17 & 6.28 & 5.11 & 1.72 & -0.13 & -0.09 & 1.00 & -1.69 & 1.63 & 0.89 & -0.06 & 0.97 & 4.37 & 1.48 & 2.02 \\
\hline & (0.783) & (0.839) & (1.233) & $(2.017)^{* *}$ & $(0.478)$ & $(-0.052)$ & $(-0.061)$ & $(0.553)$ & $(-0.82)$ & $(0.348)$ & $(0.334)$ & $(-0.028)$ & $(0.342)$ & $(2.612)^{* * *}$ & $(0.554)$ & $(2.221)^{* *}$ \\
\hline
\end{tabular}

(d)

\begin{tabular}{|c|c|c|c|c|c|c|c|c|c|c|c|c|c|c|c|c|}
\hline \multicolumn{17}{|c|}{ Difference in returns (\%) } \\
\hline $\mathrm{VMG}_{\mathrm{S}}$ & 2.51 & -0.95 & 1.73 & 5.69 & -4.67 & -4.32 & 0.60 & 3.71 & 0.53 & 1.86 & 3.65 & 1.89 & -6.57 & -3.35 & 0.33 & 0.18 \\
\hline $\mathrm{VMG}_{\mathrm{B}}$ & -1.53 & 2.33 & 4.48 & 1.74 & -3.04 & -1.38 & -0.43 & 0.69 & -2.32 & -1.38 & 5.30 & 1.16 & -1.68 & -0.45 & -0.33 & 0.21 \\
\hline $\mathrm{VMG}_{\mathrm{S}-\mathrm{B}}$ & 4.04 & -3.28 & -2.75 & 3.94 & -1.63 & -2.94 & 1.03 & 3.03 & 2.85 & 3.24 & -1.64 & 0.73 & -4.89 & -2.90 & 0.66 & -0.03 \\
\hline \multirow{2}{*}{ VMG } & 0.49 & 0.69 & 3.10 & 3.72 & -3.85 & -2.85 & 0.08 & 2.20 & -0.89 & 0.24 & 4.48 & 1.52 & -4.13 & -1.90 & 0.00 & 0.19 \\
\hline & $(0.073)$ & $(0.184)$ & $(0.64)$ & $(1.465)^{*}$ & $(-1.111)$ & $(-0.832)$ & $(0.055)$ & (1.105) & $(-0.523)$ & $(0.054)$ & $(1.61)^{*}$ & $(0.712)$ & $(-1.435)$ & $(-1.198)^{*}$ & $(0)$ & $(0.216)$ \\
\hline
\end{tabular}

The performance of small-stocks versus large-stocks portfolios and value-stocks versus growth-stocks portfolio are examined in Thailand. At the end of February of each year, stocks are sorted based on their market capitalization in descending order. Stocks in top 10\% are considered as large stocks and stocks in bottom $10 \%$ are considered as small stocks. In each size class, stocks are then ranked based on their price-to-book ratio from highest to lowest. Top $30 \%$ of the stocks with the highest $\mathrm{P} / \mathrm{B}$ ratio are selected to form the size-adjusted growth stocks and the bottoms $30 \%$ of the stocks with lowest $\mathrm{P} / \mathrm{B}$ ratio are selected to form the size-adjusted value stocks. $40 \%$ middle considered as neutral stocks. Based on this method 6 portfolios are constructed on size-P/B, which are; SV, SN, SG, BV, BN, and BG, where S and B indicate small or big stocks and V, N, and G indicate value, neutral, and growth (bottom 30\%, middle 40\%, and top 30\%), respectively. All portfolios are value-weighted. After forming portfolios at the end of February of year t, portfolios are evaluated for the next 12 months starting from March of year $t$ to end of February of year $t+1$ based on value-weighted monthly returns of the portfolios. The size effect (SMB) is the equal weight average of three small portfolios returns minus equal-weight average of three large portfolios returns. Value and growth portfolios are formed in each size. The value premium in small size category is; $\mathrm{VMG}_{\mathrm{S}}=\mathrm{SV}-\mathrm{SG}$ and for large size category is $\mathrm{VMG}_{\mathrm{B}}=\mathrm{BV}-\mathrm{BG}$. Overall VMG is the equal-weight of VMG of small stocks portfolios and VMG of large stocks portfolios. Portfolios average monthly returns, standard deviation, and Sharpe ratio are reported. The risk free that is used in this study is the 10-year government bond. The t-statistics are given in parenthesis and ${ }^{*}$ indicates that it is significant at $10 \%$, ${ }^{* *}$ indicates it is significant at $5 \%$, and ${ }^{* *}$ indicates it is significant at $1 \%$. 